\title{
What makes us tolerant of administrative burden? Race, representation, and identity
}

\section{Donavon Johnson ${ }^{*}$, Alexander Kroll*}

\begin{abstract}
This article connects the literatures of administrative burden with those of representative bureaucracy and group identity. We derive two hypotheses from extant scholarship that, adapted to the case of administrative burden, propose the following: Citizens will be more tolerant of burden if their race identity overlaps with that of the bureaucrat administering the burden, and if potential benefits are targeted at people who are similar to them. Using a survey experiment based on a stratified sample of 465 U.S. residents, we find little support for the hypotheses. In fact, while Black participants barely responded to the treatments at all, we see that white participants were most tolerant of burden when served by a white bureaucrat in a program that benefits Black clients. The article calls for more research on the subject to build nuanced theory, including contextualizing propositions across identity groups and drawing on additional theoretical ideas.
\end{abstract}

Keywords: Administrative burden, Representative bureaucracy, Identity politics, experiment

$\mathrm{R}$ easonable people tend to agree that government needs to reduce administrative burden. However, there is no general consensus on what the "right amount" of burden ought to be. What Herbert Kaufman said about red tape (1977, p. 4) seems to hold true for administrative burden in 2020 as well: "One person's red tape is another's treasured safeguard." Or, put more specifically for the purpose of our research: What one person sees as administrative burden, is considered by another person as the much-needed information requirement to effectively regulate businesses or determine program eligibility. Since discussions about the "optimal level" of burden are ultimately highly political (Herd \& Moynihan, 2018), research on factors that may ease the experience of burden or help cope with and overcome burden can be of value (Christensen, Aarøe, Baekgaard, Herd, \& Moynihan, 2020). This may include scholarship on the 'nudging potential' of redesigning program applications, the role of coproduction, or the use of information technology.

While administrative burdens are generally consequential in shaping citizen-government relations (Fox, Stazyk, \& Feng, 2020; Heinrich, 2016), we know that marginalized and disadvantaged populations with few resources are particularly detrimentally affected. Examples include cases where eligible citizens cannot benefit from government programs because they were not able to navigate through the application process or where discretion was used to discriminate against minority clients (Christensen et al., 2020; Herd \& Moynihan, 2018; Jilke, Van Dooren, \& Rys, 2018).

Our study adds to this line of research. We link the scholarship on burden to work on representative bureaucracy and group identity and ask: What makes citizens more tolerant of administrative burden? Since research has shown that varying groups of people may perceive the same rule (and its potential dysfunctions) very differently (Hattke, Hensel, \& Kalucza, 2020; Kaufmann \& Feeney, 2012), we expect people to show different degrees of tolerance of administrative burden based on how burdens are framed and experienced. In line with previous research (e.g., Jardina, 2019; Meier, 2019; Nicholson, 2008; Riccucci \& Van Ryzin, 2017), we

\footnotetext{
* Steven J. Green School of International and Public Affairs, Florida International University

Address correspondence at (djohn252@fiu.edu)

Copyright: (C) 2020. The authors license this article under the terms of the Creative Commons Attribution 4.0

International License.
} 
assume that social identity is a significant driver of human behavior, and that race plays an important role in constructing identity. Specifically, we deduce from this research that burdens will be perceived as less onerous if the citizen (i.e., a potential client for a government program) and the bureaucrat administering the burden share the same race identity. Further, we infer from previous work that burdens will be perceived as less onerous by citizens if they share the same race identity with the potential beneficiaries of a government program, and burdens are employed to restrict access to this group.

Using a sample of 465 U.S. residents (stratified into white and Black responses ${ }^{1}$ ), we test these hypotheses employing a two-factorial randomized experiment. All four groups are asked to work through the application process for a fictive government financial aid program in the area of education and, hence, have an actual experience of administrative burden. The first factor within the experiment that varies across groups is the description and visualization of white versus Black program beneficiaries whose needs can only be met if abuse is minimized via 'valid applications.' The second factor is the description and visualization of the virtual person that guides participants through the application process: a white versus Black bureaucrat.

Overall, we find little evidence that perceptions of burden vary across treatment groups based on participant race in line with the hypothesized expectations. However, we do find differences across white and Black participants, and we offer some theoretical explanations, followed by avenues for future research.

\section{Literature Review}

We understand administrative burdens as learning, psychological, and compliance costs that citizens encounter when they abide by the requirements established as a part of a government program or regulation (Herd \& Moynihan, 2018). One factor that can shape people's experiences of burden are the commonalities between the citizen and the front-line bureaucrat who is involved in the administering of information requirements related to a government program. To develop this argument, we tap into the literature on representative bureaucracy. This scholarship has shown that "matches" between citizens and bureaucrats based on a shared identity can yield positive outcomes for said citizens, either via passive signaling effects or direct action (Meier, 2019; Riccucci \& Van Ryzin, 2017; Gade \& Wilkins, 2013). We pay specific attention to passive representation, which emphasizes the benefits that accrue to clients who are being served by administrators who look like them (Andersen, 2017).

One attribute based on which shared identities may develop is race. Race-representation can result in citizens having greater appreciation, greater comfort, and overall greater trust when interacting with administrative or government agencies (Van Ryzin et al., 2014; Riccucci et al., 2017; Selden, 1998;). Specifically, Riccucci and colleagues (2014) show that African American citizens perceive a police department as well-performing, fair, and trustworthy if the department is representative of African Americans.

While the positive effects of representative bureaucracy have been widely documented, we know fairly little about its mitigating role on citizens' experience of administrative burden. Drawing on previous work on different, but related, phenomena, we expect to see the following mechanism play out. We anchor our expectations within the ambits of passive representation; a realm where a shared race identity may help establish a visible connection between citizen and bureaucrat, even before any interaction has taken place (Andersen, 2017; Llorens, Wenger, \& Kellough, 2008). Such a connection is often based on the citizen's assumption that the bureaucrat - due to the same identity - would have had similar life experiences and will understand and sympathize with the citizen (Meier, 2019; Bradbury \& Kellough, 2011). Because of this, the assumption suggests that the bureaucrat will act in the citizen's best interest, which in the case of administrative burden means to do their best to help the citizen navigate through paperwork related to information requirements.

While these are assumptions on the part of the citizen that can be triggered from a shared identity, the same mechanism may also lead to changed citizen perceptions of the administrative process itself, not just of the bureaucrat. Here, familiarity and potential trustworthiness may increase the citizen's willingness to collaborate in the process ("coproduction inducement," Lim, 2006), creating a state of mind where requirements are more likely to be seen as necessary rather than a burden.

H1: Citizens will perceive administrative burden associated with a government program as less onerous if they share the same race identity with the bureaucrat administering the burden. 
The literature on group identity provides another perspective on race and belongingness. We understand identity "as a psychological, internalized sense of attachment to a group" (Jardina, 2019, p. 4). Individuals predominantly act in the interest of in-group members and are more willing to undergo personal cost for the sake of the in-group than the out-group (Balliet, Wu, \& De Dreu, 2014). We also know that people actively protest government policies that threaten the stability of their racial in-group (Holbein \& Hassell, 2018). Group members build solidarity as a shield to enhance the wellbeing amongst members while also staving off threats from out-groups (Shelby, 2005).

Research on identity politics emerges from an understanding that political outcomes, political behavior, and political culture are products of citizens' identification with groups of similar "others" based on a racial, religious, national, ideological, demographic, or gendered identity (d'Abrera, 2017; Nicholson, 2008; Steele \& Aronson, 1995). Identity politics provide a strong sense of belonging to group members, and people are inclined to act in the interest of those whom they identify with (Gutmann, 2009).

Race has been a key dimension from which identity politics emerges (Kinder \& Winter, 2001), which has become evident in the racial patterns of voting and support during Presidential elections (Craighill \& Sullivan, 2013; Edsall, 2020). In this context of race and group identity, we examine an argument put forward by advocates of stringent standards and requirements for government programs: Administrative burdens are needed to determine program eligibility (as documented in Herd \& Moynihan, 2018). We know that despite the deleterious effects that burdens can have, they can also increase public support for government programs under some conditions (Keiser \& Miller, 2019). Research shows that identity groups, even those that are usually critical of government programs, are supportive of government assistance if the latter is directed to members of the group (Jardina, 2019; Keiser \& Miller, 2019). We adapt this point to burdens more specifically and propose that citizens are more tolerant of burdens if those are used to make sure in-group members will benefit from a government program, while access for others is restricted.

H2: Citizens will perceive administrative burden associated with a government program as less onerous if they share the same race identity with the beneficiaries of a government program.

\section{Methods}

\section{Data}

We collected data from a stratified sample of 465 United States residents (231 white and 234 Black individuals) in May-June 2020. To recruit participants, we used the crowdsourcing platform Prolific Academic that connects researchers to a pool of more than 120,000 potential survey takers (more than 38,000 are residing in the U.S.). ${ }^{2}$ The platform allows researchers to build a stratified sample such as the one needed for our research because it makes it possible to filter potential participants by demographics and other variables. This allowed us to push our survey invitation only to Black and white individuals residing in the United States. To confirm the correctness of these filters, we used additional screening questions and only began with the main survey if the Prolific filters matched with people's self-assessments regarding race and country of residence.

We also employed two attention check questions (Oppenheimer, Meyvis, \& Davidenko, 2009) and dropped survey responses from individuals who failed both checks $(\mathrm{n}=8)$. Platforms like Prolific or MTurk have been found to be useful and sufficiently validated, particularly if the subject pool of interest is a crosssection of regular citizens (Huff \& Tingley, 2015; Palan \& Schitter, 2018; Peer, Brandmarte, Samat, \& Acquisti, 2017), and applications include studies in public management (e.g., Pedersen \& Favero, 2020; Stritch, Pedersen, \& Taggart, 2017).

Our sample is $49 \%$ female, and respondents are on average 32 years old with a standard deviation of 10 years and a range between 18 and 74 years. Roughly $65 \%$ of the participants have a college degree, and out of the entire sample $35 \%$ would be considered to be the first in their family to go to college. About $63 \%$ of the respondents are currently employed. Our sample is slightly more liberal than conservative: on $0-10$ scale, where 0 is most conservative, 10 is most liberal, and 5 is the midpoint, our samples averages at about 6.5. 


\section{Inducing Administrative Burdens and Assigning Identity Treatments}

Since our research interest is in examining people's varying perceptions of administrative burden, all experimental groups had to work through the same burdensome task. We asked participants to complete an application process we created for a fictive government financial aid program in the area of education. The program description was kept broad ("financial aid to further one's education"), so that all participants may theoretically be able to serve as potential beneficiaries. The application was constructed in the shape of an online survey including questions related to applicants' educational background and future aspirations; previous experiences with government programs; demographics; and income and employment. What made the process burdensome was that the survey a) included several irrelevant questions and b) was poorly designed.

Here are some examples of the means through which we tried to induce burdens: We included three openended questions such as this one: "Before you go, please tell me, what is your career objective? Please respond in at least 160 characters." Rather than using skip questions, we put all respondents through all questions and provided long lists of choices (e.g., 20 different college concentrations). Questions about one's education went all the way back to high school. We asked for exact GPAs and provided pull-down lists that showed detailed grades separated by the first decimal $(4.0 ; 3.9 ; 3.8$ etc.). We asked twice for the location of an academic institution and listed all fifty states but not in alphabetical order. It should be noted that survey participation was voluntary and compensated.

We expect that these induced burdens will produce emotional responses that will lead to variations in our outcome variable - respondents' perception of burdens. In assessing the extent to which differing conditions of administrative burden, delay, and rule dysfunctionality in citizen-state interactions spark varying reactions, Hattke and colleagues (2020) find that bureaucratic actions are powerful enough to drive emotional responses in people who are experiencing the effects of these administrative actions. We rest our expectations in this scholarship.

Our first treatment factor is the group of people that will benefit from the government program and, indirectly, the burden associated with the application process. Specifically, we stated that the financial aid program targets "all low-income students"3 (versus "African American students with little income"). The picture associated with the statement is that of a group of white (versus Black) college students. We explained to all groups that program beneficiaries need to meet several requirements to qualify, so that the "most deserving candidates" can be selected and abuse by "free riders or dishonest persons" prevented. Our second treatment factor is the appearance of the bureaucrat (or administrator) that guides participants through the application process. The administrator pops up several times during the application process and provides explanations to the participants. His name and picture were either that of a white male ("Brett Smith") or Black male ("Tyrone Johnson") (our choice of names is based on previous research, see Einstein \& Glick, 2017).

Table 1. Randomized Treatment Design

\begin{tabular}{lll}
\hline \hline & \multicolumn{2}{l}{ Administrator } \\
\cline { 2 - 3 } Beneficiaries & $\begin{array}{l}\text { white / white } \\
(\mathrm{n}=116)\end{array}$ & $\begin{array}{l}\text { white / Black } \\
(\mathrm{n}=113)\end{array}$ \\
\cline { 2 - 3 } & $\begin{array}{l}\text { Black / white } \\
(\mathrm{n}=118)\end{array}$ & $\begin{array}{l}\text { Black / Black } \\
(\mathrm{n}=118)\end{array}$ \\
\hline $\begin{array}{l}\text { Note: } \text { The first label represents the row variables and the second label } \\
\text { represents the column variable. }\end{array}$
\end{tabular}

To make sure participants were primed as intended, we asked them one multiple-choice question after describing the program target group and another one after explaining the role of the program's information requirements in the selection of beneficiaries. When participants got these questions wrong, we showed another screen with the correct description of the program's target population and use of requirements. In total, participants were exposed two to four times (depending on whether they got our manipulation check questions 
wrong) to the images of the beneficiary group, and 11 times to the image of the administrator. ${ }^{4}$ Using different combinations of the two treatment factors, we created four treatment groups to which participants were randomly assigned (see table 1).

\section{Perceptions of Administrative Burden}

To measure participants' perceptions of the burden they experienced when working through the application process, we employed a set of 10 items. Since we are still lacking an established survey scale of administrative burden, we wrote the items following the conceptualization by Herd and Moynihan (2018). Items 1-4 tap into people's learning costs, that is in our case, the issues related to the understanding of our instructions and questions. Items 5-7 capture psychological costs, in that they measure people's experience of the entire process, including feeling stressed or uncomfortable. Items 8-10 pick up on compliance costs with a focus on responding to the application's information requirements. Item 10 can also be considered as a single-item global measure of burden, which is highly correlated with the entire list $(\mathrm{r}=0.83)$.

To make sure our items were perceived in the context of our hypothetical application process, we included the following statement: "Please recall that the purpose of asking the questions was to establish eligibility for a hypothetical financial aid program. Keeping this in mind, to what extent do you agree with the following statements." We factor analyzed the 10 items resulting in a single factor with an Eigenvalue of 5.95 and no significant cross-loadings on additional factors (see table 2). For our subsequent analysis we use a factor score consisting of the ten burden measures.

Table 2. Factor Analysis of Perceptions of Administrative Burden

\begin{tabular}{lll}
\hline \hline$\#$ & Item & $\begin{array}{l}\text { Factor } \\
\text { loading }\end{array}$ \\
\hline 01 & Reading and understanding the questions took too long & 0.777 \\
02 & Many questions seemed irrelevant & 0.717 \\
03 & Too many questions required additional research and calculations & 0.720 \\
04 & The instructions provided to me could have been more helpful & 0.660 \\
05 & Answering some of the questions made me uncomfortable & 0.732 \\
06 & The survey could have been more user friendly & 0.792 \\
07 & Overall, answering the questions was stressful & 0.830 \\
08 & The survey was too lengthy & 0.820 \\
09 & Responding to the questions took too much time & 0.822 \\
10 & Answering the questions was burdensome & 0.830 \\
\hline
\end{tabular}

Note: Principal component factoring was applied; the factor's Eigenvalue is 5.95 and no additional factors were significant. Items were measured using a 7-point scale.

\section{Results}

In our analysis, we are interested in examining differences in the perceptions of administrative burden across treatment groups sorted by race. The first step to get some insight into the issue is by comparing the means across sub-groups. We do this in table 3, where we use an index variable to capture administrative burden (ranging between 1 and 7), which for our descriptive purpose here is more illustrative than the factor score. The table provides two main insights. First, the mean for all Black groups scatters closely around the mean for the entire sample (2.34), suggesting that this group did not respond much to the four treatments. Second, this is different for the white groups, whose lowest perception of burdens (2.01), however, occurred in response to the treatment where the administrator is white but the beneficiaries are Black, not the expected white-whitewhite match. Both findings seem interesting and worth exploring further. 


\section{Table 3. Perception of Burden Means across Treatment Groups by Race}

\begin{tabular}{lllllllll}
\hline \hline & $\begin{array}{l}\text { Black beneficiaries } \\
\text { and Black adminis- }\end{array}$ & $\begin{array}{l}\text { Black beneficiaries } \\
\text { trators (1) }\end{array}$ & \multicolumn{2}{l}{$\begin{array}{l}\text { White beneficiaries } \\
\text { trators (2) }\end{array}$} & $\begin{array}{l}\text { White beneficiaries } \\
\text { and white adminis- } \\
\text { trators (3) }\end{array}$ & $\begin{array}{l}\text { lath Black adminis- } \\
\text { trators (4) }\end{array}$ \\
\hline & Black & White & Black & White & Black & White & Black & White \\
\cline { 2 - 9 } Mean & 2.33 & 2.55 & 2.41 & 2.01 & 2.33 & 2.56 & 2.27 & 2.32 \\
SD & 1.42 & 1.49 & 1.30 & 1.01 & 1.21 & 1.45 & 1.16 & 1.26 \\
Obs. & 59 & 57 & 56 & 58 & 55 & 57 & 60 & 52 \\
\hline
\end{tabular}

Note: Perceptions of administrative burden were measured on a 7-point scale. Here, we used an index variable consisting of the 10 items listed in table 2 because its interpretation is more intuitive than that of the factor score we employ in our regressions. The total mean across all groups is $2.34(\mathrm{SD}=1.30) . \mathrm{SD}=$ standard deviation; Obs = observations.

Table 4 shows the regression analysis of our treatment-race interaction framework. The coefficient of main interest is the one for the interaction effect. The table is organized by treatment group, estimating two models per group as a robustness test: one with and one without the control variables listed below the table. The interaction effect quantifies the extent to which the treatment effect on burden perceptions across the four groups varies between white (0) and Black (1) respondents.

Table 4. Regression Analysis of Burden Perceptions by Treatment Groups and Race

\begin{tabular}{|c|c|c|c|c|c|c|c|c|}
\hline \multirow[b]{2}{*}{$\begin{array}{l}\text { Benefic/admin } \\
\text { treatment }\end{array}$} & \multicolumn{2}{|c|}{$\begin{array}{l}\text { Black benefic. \& } \\
\text { Black admin. } \\
\text { (1) }\end{array}$} & \multicolumn{2}{|c|}{$\begin{array}{l}\text { Black benefic. \& } \\
\text { white admin. } \\
\text { (2) }\end{array}$} & \multicolumn{2}{|c|}{$\begin{array}{l}\text { White benefic. \& } \\
\text { white admin. } \\
\text { (3) }\end{array}$} & \multicolumn{2}{|c|}{$\begin{array}{l}\text { White benefic. \& } \\
\text { Black admin. } \\
\text { (4) }\end{array}$} \\
\hline & $\begin{array}{l}0.21 \\
(1.22)\end{array}$ & $\begin{array}{l}0.18 \\
(1.12)\end{array}$ & $\begin{array}{l}-0.36^{*} \\
(-2.69)\end{array}$ & $\begin{array}{l}-0.33^{*} \\
(-2.55)\end{array}$ & $\begin{array}{l}0.20 \\
(1.20)\end{array}$ & $\begin{array}{l}0.19 \\
(1.21)\end{array}$ & $\begin{array}{l}-0.05 \\
(-0.31)\end{array}$ & $\begin{array}{l}-0.03 \\
(-0.20)\end{array}$ \\
\hline Black respondent & $\begin{array}{l}0.03 \\
(0.30)\end{array}$ & $\begin{array}{l}0.11 \\
(1.12)\end{array}$ & $\begin{array}{l}-0.13 \\
(-1.20)\end{array}$ & $\begin{array}{l}-0.07 \\
(-0.63)\end{array}$ & $\begin{array}{l}0.03 \\
(0.25)\end{array}$ & $\begin{array}{l}0.09 \\
(0.86)\end{array}$ & $\begin{array}{l}-0.02 \\
(-0.16)\end{array}$ & $\begin{array}{l}0.04 \\
(0.42)\end{array}$ \\
\hline $\begin{array}{c}\text { Treatment } \\
\times \text { Black }\end{array}$ & $\begin{array}{l}-0.22 \\
(-0.93)\end{array}$ & $\begin{array}{l}-0.27 \\
(-1.15)\end{array}$ & $\begin{array}{l}0.43^{*} \\
(2.14)\end{array}$ & $\begin{array}{l}0.44^{*} \\
(2.18)\end{array}$ & $\begin{array}{l}-0.20 \\
(-0.90)\end{array}$ & $\begin{array}{l}-0.18 \\
(-0.85)\end{array}$ & $\begin{array}{l}-0.02 \\
(-0.08)\end{array}$ & $\begin{array}{l}0.01 \\
(0.02)\end{array}$ \\
\hline Constant & $\begin{array}{l}-0.04 \\
(-0.54)\end{array}$ & $\begin{array}{l}-0.49 * \\
(-2.19)\end{array}$ & $\begin{array}{l}0.10 \\
(1.24)\end{array}$ & $\begin{array}{l}-0.32 \\
(-1.42)\end{array}$ & $\begin{array}{l}-0.04 \\
(-0.50)\end{array}$ & $\begin{array}{l}-0.48^{*} \\
(-2.09)\end{array}$ & $\begin{array}{l}0.02 \\
(0.29)\end{array}$ & $\begin{array}{l}-0.43 \\
(-1.96)\end{array}$ \\
\hline Controls & No & Yes & No & Yes & No & Yes & No & Yes \\
\hline $\mathrm{R}^{2}$ & 0.004 & 0.047 & 0.013 & 0.055 & 0.004 & 0.046 & 0.001 & 0.043 \\
\hline Obs. & 454 & 449 & 454 & 449 & 454 & 449 & 454 & 449 \\
\hline
\end{tabular}

Note: $* \mathrm{p}<0.05$ (two-tailed tests); t statistics in parentheses; robust standard errors. The dependent variable is an administrative burden factor score, consisting of the item listed in table 2. Controls include gender, age, college degree, status "first in family to go to college," currently employed, and liberal ideology. "benefic" = beneficiaries; "admin" = administrator.

The only significant interaction effect is that for the treatment, where the beneficiaries are Black and the administrator is white. In this scenario, burdens are being perceived 0.43 or 0.44 points higher by Black participants as opposed to white ones. While the results for the first treatment group are not significant in our sample of about 450 observations, the differences across respondents are still of substantive sizes. Considering that the dependent variable in this table is constructed as a factor score with a mean value of zero and a standard deviation of one, the interaction coefficients suggest a $22 \%$ to $27 \%$ standard deviation difference between white and Black participants. Specifically, what this means is that when both beneficiaries and the administrator are 
Black, then the perception of burden by Black applicants is about a quarter of a standard deviation lower than that by white applicants.

Table 5. Marginal Effects from Regression Analysis for Race Variable

\begin{tabular}{lllllllll}
\hline \hline & \multicolumn{2}{l}{$\begin{array}{l}\text { Black benefic. \& } \\
\text { Black admin. } \\
(1)\end{array}$} & $\begin{array}{l}\text { Black benefic. \& } \\
\text { white admin. } \\
(2)\end{array}$ & $\begin{array}{l}\text { White benefic. \& } \\
\text { white admin. } \\
(3)\end{array}$ & $\begin{array}{l}\text { White benefic. \& } \\
\text { Black admin. } \\
\text { (4) }\end{array}$ \\
\cline { 2 - 10 } & White & Black & White & Black & White & Black & White & Black \\
\hline $\begin{array}{c}\text { Benefic/admin } \\
\text { treatment }\end{array}$ & 0.21 & -0.01 & $-0.36^{*}$ & 0.08 & 0.20 & 0.00 & -0.05 & -0.07 \\
\hline
\end{tabular}

Note: $* \mathrm{p}<0.05$ (two-tailed tests); t statistics in parentheses; robust standard errors. Marginal effects are predicted from the regression models (without controls) shown in table 4.

Table 5 predicts specific marginal effects from the models presented in table 4 . While table 4 shows whether the differences in perceptions between white and Black respondents vary significantly, table 5 provides us with a straightforward illustration of the point estimate for the treatment effects of white and Black participants. In line with our previous observations, we see that all treatment effects for Black respondents are virtually zero, while there is more variation among white participants. For white respondents, our treatment reduced burden (significantly) when in the second experimental group, whereas perceptions of burden increased (insignificantly) for groups one and three.

\section{Discussion and Conclusion}

In this article, we connected the literatures on administrative burden with those of representative bureaucracy and racial group identity. Adopting previous findings to our study of the administrative burden phenomenon, we derived two guiding hypotheses: Perceptions of burden will be lower if 1) citizens and administrators match in terms of their race identity and 2) citizens' race identity matches the one of potential program beneficiaries. Using a two-factorial survey experiment based on a race-stratified sample of 465 U.S. residents, we found fairly little support for these hypotheses. In fact, white and Black participants responded somewhat differently to our treatments, and the treatment that triggered a greater tolerance of burdens was a hybrid one: Here, white applicants interacted with a white administrator, but the beneficiaries of the program in question were largely Black.

One explanation of our hybrid finding is that theories around administrative burden and race may be more complex than what adaptations of findings from the area of representation and identity might suggest. There are several mechanisms that could help explain why white program applicants show the most tolerance for burdens when they are being served by white administrators but, at the same time, program beneficiaries include non-white citizens. First, the support for identity politics is largely grounded in self-interest motives channeled through collective actions of homogenous groups. However, research has documented that behavior can be motivated by a variety of (often conflicting) values (Witesman \& Walters, 2014). Second, one known restriction to self-interested behaviors is a person's self-image (Bonner et al., 2017). According to this view, while people try to maximize gains, they would only engage in related behavior as long as they can still maintain a positive self-image; and taking advantage of disadvantaged populations can significantly curb such an image. Third, our finding could be explained by white paternalism that tends to course-correct for the impediments that often endure due to the benefit of white privilege (Baker, 2015; Ben-Ishai, 2012).

We need further research to develop theory that connects burden, race, and identity. One route would be to elaborate on our client-administrator match and model active interaction (virtually or via the means of a laboratory experiment) as opposed to passive reception. Involving the administrator more actively in the process of service delivery will likely strengthen the priming effect. Future research could also benefit from designing more burdensome treatments in order to effectively tease out the effects of administrative burden. Conducting in-person experiments for real programs can provide the conditions for actual and heavier burdens to be levied by researchers in controlled research settings. 
Like other research, our article is not free from limitations. The fact that we had to use the term "lowincome students" (complemented with a picture of white students) instead of "white students," in order to create a realistic and believable treatment, may have curbed our priming effects. Like with most experiments our focus is on internal rather than external validity. Nevertheless, generalizability may be another limitation of our study, although the use of a nationwide sample of U.S. residents mitigates this problem to a good extent.

For public management practice, the article points to the fact that the perception of burden can sometimes be as important as the actual information requirement itself. This is not to say that governments should not engage in the reduction of burden. But in cases in which discussions about burdens (i.e., information requirements) are so politicized that consensus is unlikely, practitioners may want to think through options to ease experiences of burden via means of nudging, coproduction, or information technology.

Overall, we think that addressing the question as to whether perceptions and experiences of burden vary based on the race and identity of applicants constitutes an exciting and promising research program. This article examined the impact of race-identity matches between clients and administrators as well as clients and program beneficiaries. Our research suggests effective theories will require nuanced specification rather than adaptation of findings from existing scholarship. Our observation that white and Black participants responded differently to our treatments indicates that theoretical propositions may need to be contextualized across different identity groups. We consider our study a first step in a novel research direction, but developing generalizable theory in this area certainly calls for further research.

\section{Notes}

1. In this article, we contrast results between white/Caucasian on one side and Black/African American on the other. We capitalize 'Black' throughout (retrieved 6/22/2020).

2. https://www.prolific.co/demographics (retrieved 6/22/2020)

3. We used the term "low-income students" (and complemented it with a picture of white students) as opposed to "white students" because referring to a program that only serves the latter would have been an odd and artificial treatment.

4. The manipulation check is different from the attention check. The former was used to make sure our treatments were understood as intended (the treatment screen was shown twice to a few participants who did not pass the manipulation check question), whereas the latter tested whether participants generally paid attention to the survey, and this could lead to subjects being dropped from the study.

\section{References}

Andersen, S. (2017). From passive to active experimental evidence on the role of normative values in shaping white and minority bureaucrats' policy attitudes. Journal of Public Adminstration Research and Theory, 27(3), 400-414.

Balliet, D., Wu., J., \& De Dreu, C. (2014). Ingroup favoritism in cooperation: A meta-analysis. psychological bulltin, 140(6), 1556-1581.

Baker, A. (2015). Race, paternalism and foreign aid: Evidence from U.S. public opinion. American Political Science Review, 109(1), 93-109.

Ben-Ishai, E. (2012). The new paternalism: An analysis of power, state intervention, and autonomy. Political Research Quarterly, 65(1), 151-165.

Bonner, J., Greenbaum, R., \& Quade, M. (2017). Em ployee unethical behavior to shame as an indicator of self-image threat and exemplification as a form of self-image protection: The exacerbating role of supervisor bottom-line mentality. Journal of Applied Psychology, 102(8), 1203-1221.

Bradbury, M., \& Kellough, J. (2011). Representative bureaucracy: Assessing the evidence on active representation. American Review of Public Administration, 41(2), 157-167.

Christensen, J., Aarøe, L., Baekgaard, M., Herd, \& Moynihan, D. (2020). Human capital and administrative burden: The role of cognitive resources in citizenstate interactions. Public Administration Review, 80(1), 127-136.

Craighill, P., \& Sullivan, S. (2013). The wide racial gap in Obama's presidential elections, in 2 charts. The Washington Post. https://www.washingtonpost.com/news/the-fix/wp/2013/08/28/thewide-racial-gap-in-obamas-presidential-elections-in2-charts/ (retrieved 6/22/2020). 
d'Abrera, B. (2017). The rise of identity politics: An audit of history teaching at Australian universities in 2017. Melbourne: Institute of Public Affairs.

Edsall, T. (2020). Trump has his sights set on black voters. The New York Times. https://www.nytimes.com/2020/03/04/opinion/trump-black-voters.html (retrieved 6/22/2020).

Einstein, K. L., \& Glick, D. M. (2017). Does race affect access to government services? An experiment exploring street-level bureaucrats and access to public housing. American Journal of Political Science, 61(1), 100-116.

Fox, A., Stazyk, E., \& Feng, W. (2020). Administrative easing: Rule reduction and medicaid enrollment. Public Administration Review, 80(1), 104-117.

Gade, D., \& Wilkins, V. (2013). Where did you serve? Veteran identity, representative bureaucracy, and vocational rehabilitation. Journal of Public Administration Research and Theory, 23(2), 267-288.

Gutmann, A. (2009). Identity in democracy. Princeton, NJ: Princeton Universiry Press.

Hattke, F., Hensel, D., \& Kalucza, J. (2020). Emotional responses to bureaucratic red tape. Public Administration Review, 80(1), 53-63.

Heinrich, C. (2016). The bite of administrative burden: A theoretical and empirical investigation. Journal of Public Administration Research and Theory, 26(3), 403-420.

Herd, P., \& Moynihan, D. (2018). Administrative burden: Policymaking by other means. Nyew York: Russel Sage Foundation.

Holbein, J., \& Hassell, H. (2018). When your group fails: The effect of race-based performance signals on citizen voice and exit. Journal of Public Administration and Theory, 29(2), 268-286.

Huff, C., \& Tingley, D. (2015). Who are these people? Evaluating the demographic characteristics and political preferences of MTurk survey respondents. Research and Politics, 2(3), 1-12.

Jardina, A. (2019). White identity politics. Cambridge: Cambridge University Press.

Jilke, S., Van Dooren, W., \& Rys, S. (2018). Discrimination and administrative burden in public service markets: Does a public-private difference exist? Journal of Public Administration Research and Theory, 28(3), 423-439.

Kaufman, H. (1977). Red tape: Its origins, uses, and abuses. Washington, D.C.: The Brookings Institution.

Kaufmann, W., \& Feeney, M. (2012). Objective formalization, perceived formalization and perceived red tape. Public Management Review, 14(8), 1195-1214,

Keiser, L., \& Miller, A. (2019). Does administrtaive burden influence public support for government programs? Evidence from a ssurvey experiment. Public Administrtaion Review, 80(1), 137-150.

Kinder, D., \& Winter, N. (2001). Exploring the racial divide: Blacks, whites, and opinion on national policy.
American Journal of Political Science, 45(2), 439-456.

Lim, H.-H. (2006). Representative bureaucracy: Rethinking substantive effects and active representation. Public Administration Review, 66(2), 193-204.

Llorens, J., Wenger, J., \& Kellough, E. (2008). Choosing public sector employment: The impact of wages on the representation of women and minorities in state bureaucracies. Journal of Public Administration Research and Theory, 18(3), 397-413

Meier, K. (2019). Theoretical frontiers in representative bureaucracy: New directions for research. Perspectives on Public Management and Governance, 2(1), 39-56,

Nicholson, L. J. (2008). Identity before identity politics. Cambridge, UK: Cambridge University Press.

Oppenheimer, D, Meyvis, T., \& Davidenko, N. (2009). Instructional manipulation checks: Detecting satisficing to increase statistical power. Journal of Experimental Social Psychology, 45(4), 867-872.

Palan, S., \& Schitter, C. (2018). Prolific.ac-A subject pool for online experiments. Journal of Behavioral and Experimental Finance, 17, 22-27.

Pedersen, M., \& Favero, N. (2020.) Social distancing during the Covid-19 pandemic: Who are the present and future non-compliers? Forthcoming in Public Administration Review (https://doi.org/10.1111/puar.13240).

Peer, E., Brandmarte, L., Samat, S., \& Acquisti, S. (2017). Beyond the Turk: Alternative platforms for crowdsourcing behavioral research. Journal of Experimental Social Psychology, 70, 153-163.

Riccucci, N., \& Van, R. G. (2017). Representative bureaucracy: A lever to enhance social equity, coproduction, and democracy. Public Administration Review, 77(1), 2130 .

Riccucci, N., Van Ryzin, G., \& Lavena, C. (2014). Representative bureaucracy in policing: Does it increase perceived legitimacy? Journal of Public Administration Research and Theory, 24(3), 537-551.

Selden, S. (1998). The promise of representative bureaucracy: Diversity and responsiveness in a government agency: Diversity and responsiveness in a government agency. New York: Routledge.

Shelby, T. (2005). We who are dark: The philosophical foundations of black solidarity. Cambridge, MA: Harvard University Press.

Steele, C., \& Aronson, J. (1995). Stereotype threat and the intellectual test performance of African Americans. Journal of Personality and Social Psychology, 69(5), 797-811.

Stritch, J. M., Pedersen, M. J., \& Taggart, G. (2017). The opportunities and limitations of using Mechanical Turk (MTURK) in public administration and management scholarship. International Public Management Journal, 20(3), 489-511.

Witesman, E., \& Walters, L. (2014). Public service values: A new approach to the study of motivation in the public sphere. Public Administration, 92(2), 375-405. 